\title{
The Discussion on the Grassroots Party Management in New Era
}

\author{
Xi Liü, a
}

${ }^{1}$ State Grid Corporation of China Hebei Training Center, Shijiazhuang, Hebei, 050031

\section{Keywords: Grassroots Party Management, New Era, Discussion}

\begin{abstract}
In the process of building the party, party management is one of the important contents of them. In the socio-economic development, the increasingly stringent requirements of party building, administrative tasks grassroots party cadres thus become very difficult. Combined with the actual situation, raise grass-roots party management understanding, analysis arising in the ordinary course of Party construction problems, and how to better manage the work of grass-roots party status quo put forward their views and Countermeasures.
\end{abstract}

\section{Introduction}

Grass-roots party organizations was the basis of the ruling party, it is an important guarantee of modernization. Gestures party junior officers represents the party's image, is the basis for the work of the party. Their ability to work and demeanor will have a direct impact on the party and society. But in the current period of social transformation, some grass-roots party members and cadres apathy party's purpose, negligent party spirit so that adverse effects. So now to promote grassroots party members and cadres bear in mind the purpose of the party, close ties with the masses, improve the grass-roots party members and cadres relationship from the system. Currently the party cadres to improve the quality of correct thinking party personnel to adapt to the new situation as the top priority of the current grass-roots party work.

Party management is an important part of our party building work, good management of party affairs but also directly affect the quality level of the entire party building work. In the new period of socialist development, China's increasing emphasis on grass-roots party organizations in the basic position of the enterprise development, especially with the deepening development of market economic reform, enterprises have to raise the importance of grass-roots party work, to strengthen party cadres training, optimization party management mode, so that enterprises carry out grass-roots party work in line with the new era of social development situation. But from the current situation, enterprises grassroots party work are still some problems in the development process, you can not effectively play the role of guide and service, which requires grassroots party workers and improve their overall quality, increase investment in grassroots party work and reform, improve work quality and efficiency, thereby effectively grassroots party organizations to play an active role in the enterprise modernization and development.

\section{The Importance of Grassroots Party Management}

The essential element of party work is the management of their own party, the overall management of the party daily party work is all part of the party staff, which is the foundation of the party grassroots organizations all work and its effectiveness, is to implement the Party's line, principles, policies, and tasks fighting force. Grass-roots organization and management related to the party's principles and policies fully implement at the grassroots level, is related to building a moderately prosperous society and building a socialist harmonious society process is related to the whole party unity of thinking on reform and opening up and socialist modernization drive overall. Only the grass-roots party work to do in order to achieve better management of their party, the party management is a very serious work. This work is an important part of the work of party building, through the management and recording of things within the party, to guarantee the smooth development of the party building. Once the lack of grass-roots party work, mission and objectives of the party are to be carried out will be greatly hampered, if not impossible to achieve and 
implement. Therefore, the importance of grass-roots party workers to improve party work and improve their ability to work, it becomes extremely important.

\section{The Current Situation of Grassroots Party Management Work}

The Grassroots Party Management Mechanism Is Not Perfect Enough. As the socialist market economic system reform, enterprise management has also undergone a lot of changes, most companies have begun to focus on conduct and enhance the economic efficiency of the operation and management work, and neglect as business activities basis for the grass-roots party work, work related mechanism is not perfect, the lack of coordination and normative, and even some companies are not responsible for the grass-roots party affairs departments or personnel, which causes the enthusiasm of employees cannot be effectively mobilized, businesses cohesion cannot be promoted, is not conducive to long-term stable development of enterprises.

For party-building workforce does not pay attention to make the relevant institutions no party work management mechanism and improve the timeliness of updates, resulting in party affairs management mechanism fundamentally unsound. For example, if there are no investment funds, some of the management and operation mechanism of party building work cannot be carried out, such as education and training, study audit work.

The Comprehensive Quality of Grassroots Party Cadres Is Not High. Due to lack of attention to the grass-roots enterprise party work, so in the training of party cadres do not in place. First, many companies lack the overall quality of party cadres to carry out party work necessary, no relevant professional knowledge as a basis, in the actual party to carry out work-related business skills cannot meet the actual needs. Secondly, although some companies have a special party and personnel departments, but many party cadres led by other departments are part-time, work busy, so there is no more time to learn the necessary complement and party building, knowledge structure comparison of single, cannot meet the needs of businesses in the new grassroots party work. In addition, most companies grassroots party cadres ages generally too large, ideologically relatively conservative, but cannot update their knowledge structure and ideas to adapt to new forms of social development, leading cadres at the grass-roots party faced with new situations and what to do when the problem, the lack of innovation, is not conducive to the modernization of enterprises.

Effectiveness of the Grass-Roots Party Management Is Poor. Under the new situation of social development, although most enterprises have realized the importance of party work, have begun to take some specific action, but the actual effect of the conversion of grass-roots party management is not strong, mainly because companies in grass-roots party the lack of contact with their actual working conditions, lack of internal support necessary to carry out party work environment and atmosphere, the mode is still relatively backward, in the work mode is relatively simple, the lack of flexibility and innovation, which led to the grass-roots enterprises party management effectiveness difficult to be improved.

It Lacks of Supervision System. When there is a dispute at work, but just another responsibility to refuse walking a fine line, there is no clear division and lack of supervision. Responsibilities to individuals cannot do, not only the problem cannot be a good solution, between each employee's decline makes the relationship between them is affected, hurt cohesion. Lack of personnel led model, not the power of example, employees are not standards of behavior is bound to cause great impact on working. Lax management, managers cannot do reward and punishment, cannot be treated equally, harboring the wrong part of the staff, encourage their arrogance caused dissatisfaction of other personnel, the formation of contagion.

\section{The New Effective Ways of Grassroots Party Management Work}

Strengthen the Ideological Importance to Fully Understand the Importance of Party Workforce Construction. So that the grass-roots party workers to establish the times of ideology and strengthen leadership and attention to party work unit is a key prerequisite for the smooth unfolding of the party. Grass-roots party organizations and units to seriously study the party's 
ideological line, principles and policies to strengthen the party's construction workforce deep understanding, a clear understanding of the importance of party staff team building, it is the unit of the party building work to promote the reform of key points raise the maximum extent the ideological consciousness of party members, adhere to the masses from the masses to approach, to play a leading role in ideological and political work of the masses, so that the people work together to promote the development of the unit, the unit increase benefit. So the unit from the leadership to ordinary party members to be fully aware of the importance of party building workforce, and actively support and participate in the organization or related work of party building. CPC Central Committee and local Party organs at all levels to organize and hold consultation sessions before by local authorities and then communicated to the party organization, transfer layers, to ensure publicity in place. Second, it can also built special website, or with the famous website Sina, Tencent and other cooperation such as the publicity of party building work on top. With online media, or is the power of traditional media to strengthen party building work.

Strengthen the Quality of Education and Improve Service Levels. First Party wants to emphasize the quality of education, which is used to measure the ability to work with members of the service level standards. Quality education from party members and cadres grabbed begin to raise the level of education in Marxist theory of Party members and cadres. "Important Thought of Three Represents party members and cadres ideological armed, so party members and cadres of the firm belief that China's socialist construction characteristics, and constantly improve their own quality of theory and ideological and political quality, thus improving the level of service for the people, followed by a good job of party members legal education, strengthen law-abiding members of the socialist concept of honor ideas. Therefore, we must strengthen the quality of education, grass-roots party members take the lead in the study of law, law-abiding, according to law, improve the legal concept of party members, thereby enhancing the Party members to resist corruption ability to adhere to the people responsible for the purpose, discipline, integrity, improve service levels. Finally, we need to emphasize grassroots party members and business skills education. as a Chinese Communist Party members, in order to give full play to the exemplary vanguard itself, it must master the business skills to do their jobs, the completion of the work on a task. Therefore, for the purposes of party members, develop business skills are very necessary in strengthening the Party's ideological education is also necessary to reinforce the party business skills education. Only by improving the business skills of party members, in order to improve the quality and efficiency of party members, party members to give full play to the functions of serving the people wholeheartedly.

Establish and Improve Rules and Regulations of the Party. Improve the management mechanism. Improve the management mechanism first of all we have to support the substance. Government or organization to provide the necessary financial outlay to party building institutions so that the associated management mechanism to work properly, the work can be carried out in depth.

"Improve the evaluation system, strengthen supervision of party members and periodic evaluation of the CPC Central Committee Party of the provisions of the party constitution has been written. Party members and regular assessment to ensure the quality of party members, party members to ensure that the thinking and behavior of party members in line with the requirements. units must first clear job responsibilities of staff each party, and then the fulfillment of their responsibilities for regular examination and evaluation can take leadership to observe, as the way the masses secret ballot to conduct a comprehensive assessment and monitoring of each party workers facilitate their work and ensure their complete thought is in the direction of the development of the party. Party members of the evaluation, we must rely on scientific and reasonable evaluation mechanism. The custom indicators to try to be fair, transparent, evaluation results have convinced people oral, forming a good atmosphere for everyone to excellence. implement incentive mechanisms and criticism of the General Assembly was held in recognition of members, to be encouraged and related material reward for an outstanding member of the performance is poor, lazy, and discipline of party members to be severely criticized and punished in 
China's current situation, the awards ceremony held regularly, but rarely consciously held criticism of the general Assembly, usually a serious law and discipline phenomenon public pressure was held. Party ideological work is to constantly supervise in order to nip in the bud, the wrong thinking and behavior stifled in signs, in order to avoid further errors. Therefore, to improve team building staff members, we must dare to self-test self-examination, strictly regulate party workers of thought and behavior.

Improve the Personnel System, Strengthen Education and Training. The social development has entered a new era, but the staff is still the old party members based. The old party members, although experienced, but cannot avoid thinking obsolete, cannot keep up the pace, and if the old members retired, then the party will work. Successors ", and therefore, to strengthen the party's construction workforce to improve the employment system, improve the relevant Recruitment of personnel system can improve the welfare of party members, through superior material rewards to attract young people; It can be followed to improve Party internal organizations, by reducing the phenomenon of relationship sit high for young people to provide a good development and improvement; and finally recruitment procedures must be strictly enforced to ensure that there is capacity, high ideological consciousness of talented people into the party organization of work in short, the recruitment. The talented people is to ensure that the key to advancing the work of party. Party organizations should regularly conduct lectures to familiarize them with the party constitution, party policy, and related business training to improve the professional quality of Party members, work efficiency, thereby promoting grass-roots party work carried out smoothly.

\section{Conclusion}

Grass-roots party management companies play in the process of modernization an important role for some problems in carrying out grass-roots party enterprise management faced the need to improve grass-roots party enterprise management system construction, but also to increase grassroots party cadres education and training, improve their overall quality, and strengthen the implementation of grassroots party organizations, so that party management effectiveness can be improved.

\section{References}

[1] Zhou Shasha, Li Jingyuan. Foreign Entrepreneurs, Vol. 6 (2012) No 53, p.25-26

[2] Wang Qunyong. Research on Modern Enterprise, Vol. 12 (2013) No 27, p.74-76

[3] Zhang Yuping. Hou XuSi. Business Office, Vol. 30 (2011) No 19, p.144-145

[4] Wang Kuailiang. Modern Enterprise Culture, Vol. 29 (2008) No 27, p.21-23

[5] Zhang Gongxu, Sun Jing. Technology and Enterprise, Vol. 8 (2014) No 27, p.57-60 